\title{
A New Bioluminescent Rat Prostate Cancer Cell Line: Rapid and Accurate Monitoring of Tumor Growth
}

\author{
Mi Sook Lee ${ }^{1,2^{\dagger}}$, Jae-In Jung ${ }^{1,5^{\dagger}}$, Seung-Hae Kwon', In-sop Shim², Dae-Hyun Hahm², \\ Jeong-Jun $\mathrm{Han}^{3}$, Daeseok Han', Jung Han Yoon Park ${ }^{5}$ and Song Her ${ }^{1}$ * \\ ${ }^{1}$ Division of Bio-Imaging, Chuncheon Center, Korea Basic Science Institute, Chuncheon 200-701, Republic of Korea \\ ${ }^{2}$ Department of Medical Science, Graduate School of East-West Medical Science Kyung Hee University, Seoul 130-701, Republic of Korea \\ ${ }^{3}$ Glonet, Doosan Co., Yongin, 448-795, Republic of Korea \\ ${ }^{4}$ Korea Food Research Institute, Seongnam 463-746, Republic of Korea \\ ${ }^{5}$ Department of Food Science and Nutrition, Hallym University, Chuncheon 200-702, Republic of Korea
}

Received September 27, 2010 / Accepted November 11, 2010

\begin{abstract}
Caliper measurements of tumor volume have been widely used in the assessment of tumors in animal models. However, experiments based on caliper data have resulted in unreliable estimates of tumor growth, due to necrotic areas of tumor mass. To overcome this systematic bias, we engineered a new luciferase-expressing rat prostate cancer cell line (MLL-Luc) that produces bioluminescence from viable cancer cells. MLL-Luc cells showed a strong correlation between bioluminescence intensity and cell number $\left(R^{2}=0.99\right)$ and also accurately quantified tumor growth, with reduced bioluminescence signals caused by necrotic cells in a subcutaneous MLL-Luc xenograft model. The accurate quantification of tumor growth with bioluminescence imaging (BLI) was confirmed by a better antitumor effect of combination chemotherapy, compared to that based on caliper measurements with a correlation between the bioluminescence signal and tumor volume $\left(R^{2}=0.84\right)$. These data suggest that bioluminescent MLL xenografts are a powerful and quantitative tool for monitoring tumor growth and are useful in evaluating the efficacy of anticancer drugs, with less systematic bias.
\end{abstract}

Key words : Bioluminescent imaging, luciferase, prostate cancer xenograft, rat MAT LyLu (MLL) cells

\section{Introduction}

Animal models are important tools for investigating tumor development mechanisms and screening therapeutic drugs [12]. Neoplastic mouse models have commonly been monitored by single-point weight or caliper measurements of tumor volume, which are based on tumor anatomical mass. However, a tumor mass contains not only viable cells but also necrotic regions. Thus, the effects of treatments on tumor growth are not accurately assessed by these measurements, which also require groups of animals to be sacrificed at specific time points and limit real-time observations within the same animal both during and after treatment. A technique for the noninvasive and real-time detection of tumors would allow more accurate monitoring of neoplastic progression and better assessment of the time course of treatment [1,2].

Bioluminescence imaging (BLI), which is based on visi-

\footnotetext{
${ }^{\dagger}$ These authors contributed equally to this work. *Corresponding author

Tel : +82-33-250-7394, Fax : +82-33-255-7273

E-mail : swher@kbsi.re.kr
}

ble light emission from luciferase-expressing cells, is a rapid and sensitive method for monitoring and tracking tumor development [10,11]. In BLI assessments of tumor growth, the bioluminescence signal is derived from viable cells only, not from necrotic areas, in a tumor, providing an accurate quantification of viable cancer cells in a tumor $[3,4,7,9]$. In this study, we developed a new bioluminescent rat prostate cancer cell line and evaluated it in the xenograft model.

\section{Materials and Methods}

\section{Animals}

Male BALB/c nude mice (4 weeks old) were purchased from Orient (Gyeonggi-do, Korea). The use and care of the animals were reviewed and approved by the Institutional Animal Care and Use Committee at the Korea Basic Science Institute (KBSI), and all animal procedures were conducted in accordance with the "Guide for the Care and Use of Laboratory Animals," issued by the Laboratory Animal Resources Commission of KBSI. 
Rat prostate cancer cells stably expressing firefly luciferase

MAT-LyLu (MLL) cells (ATCC, Rockville, MD, USA) were cultured in DMEM (Lonza, Walkersville, MD, USA) supplemented with $10 \%(\mathrm{v} / \mathrm{v})$ fetal bovine serum (Hyclone, Logan, UT, USA) and were transfected with a CMV promoter-driven firefly luciferase expression construct (pcDNA3.1-Luc; a gift from Dongmin Kang, Ewha University, Seoul, Korea) using Lipofectamine reagent (Invitrogen, Carlsbad, CA, USA). Transfected cells were grown for 2 weeks under antibiotic selection (hygromycin B; Sigma, St. Louis, MO, USA), and surviving colonies were screened for bioluminescence in complete medium supplemented with $150 \mu \mathrm{g} / \mathrm{ml}$ D-luciferin (Biosynth International, Inc., Naperville, IL, USA) using an IVIS200 system (Xenogen, Alameda, CA, USA). Bioluminescent, antibiotic-resistant, single-cell clones were selected and characterized for stable bioluminescence in vitro and tumorigenic potential in vivo.

\section{Histological assay}

To confirm the presence of necrotic cells, selected tissues were excised from the mice at necropsy, and the paraffin-embedded tissues were sectioned at $8 \mu \mathrm{m}$. The sections were stained with hematoxylin and eosin (H\&E) and examined by light microscopy. For immunostaining, the sections were stained with goat anti-luciferase antibody (Chemicon International Inc., Temecula, CA, USA) and subsequently incubated with Alexa488-labeled donkey anti-goat antibody (Molecular Probes, Inc., Eugene, OR, USA). Fluorescence signals were analyzed using a confocal laser scanning microscope (LSM-5 and LSM System, ver. 3.98; Carl Zeiss, Oberkochen, Germany).

\section{Subcutaneous primary tumor model}

Mice were anesthetized by exposure to $1-3 \%$ isoflurane, and $100 \mu$ sterile Dulbecco's phosphate-buffered saline containing $5 \times 10^{5}$ MLL-Luc cells was injected into the dorsal flank. Subcutaneous tumor growth was monitored by BLI and external caliper measurements of tumor volume $\left(\mathrm{L} x \mathrm{~W}^{2} / 2\right)$ for 12 - 15 days. The imaging time ranged from 1 to $3 \mathrm{~min}$, depending on the size of the primary tumor. Recombinant tissue inhibitor of metalloproteinases (rTIMP-2) and 5-FU were dissolved in saline and administered by intraperitoneal (i.p.) injection every 2 days, beginning 5 days after cell injection.

\section{BLI analysis}

BLI was performed using an IVIS200 imaging system, as described previously $[6,8]$. For in vivo imaging, mice were given the substrate D-luciferin $(150 \mathrm{mg} / \mathrm{kg})$ by i.p. injection, and then anesthetized. Regions of interest around the tumor sites were identified on the displayed images and quantified as photon flux $(\mathrm{p} / \mathrm{s})$ using Living Image $^{\circledR}$ software (Xenogen).

\section{Statistical analyses}

Significant differences were detected by paired $t$-tests in all cases. The results are presented as means \pm SEM. An asterisk ${ }^{*}$ indicates $p<0.05$.

\section{Results and Discussion}

To efficiently quantify tumor growth with BLI, we engineered metastatic rat MAT-LyLu (MLL) cells that stably and constitutively expressed a luciferase enzyme. The MLL

A

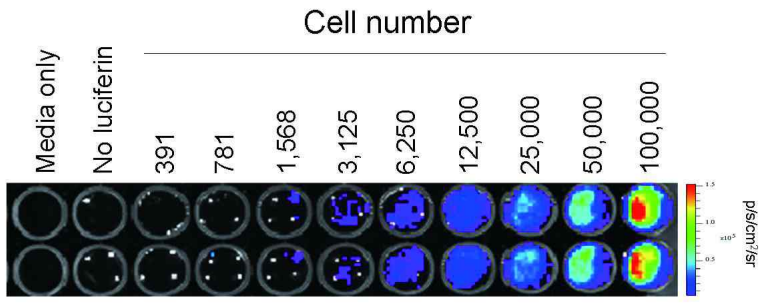

B

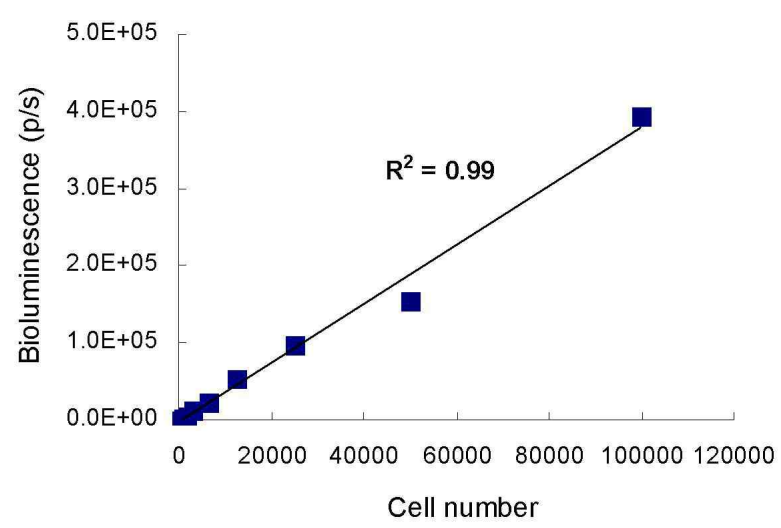

Fig. 1. Correlation between bioluminescence imaging (BLI) and cell number. MLL-Luc cells were serially diluted and imaged for $1 \mathrm{~min}$ after adding D-luciferin substrate to the medium. Wells containing cells with no luciferin or medium with no cells were included as negative controls. (A) BLI of MLL-Luc cells. (B) The increases in bioluminescence $(\mathrm{p} / \mathrm{s})$ and cell number showed a strong linear correlation $(n F 7)$. 
cells were stably transfected with an expression vector encoding firefly luciferase. Three clonal cell lines were initially selected, and the highest bioluminescent derivative MLL cell line (MLL-Luc) was used in this study. The MLL-Luc cells showed a strong correlation $\left(R^{2}=0.99\right)$ between bioluminescence intensity and cell number in vitro (Fig. 1).

To investigate their tumorigenic potential, the cells were subcutaneously injected into the dorsal flank of mice. Figs. $2 \mathrm{~A}$ and $2 \mathrm{~B}$ show that BLI increased up to 10 days

A

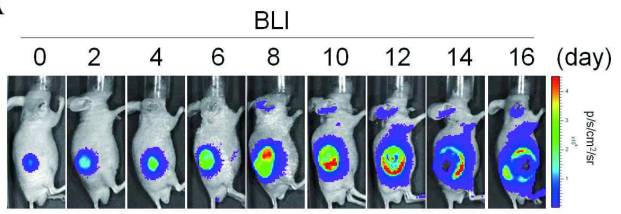

B

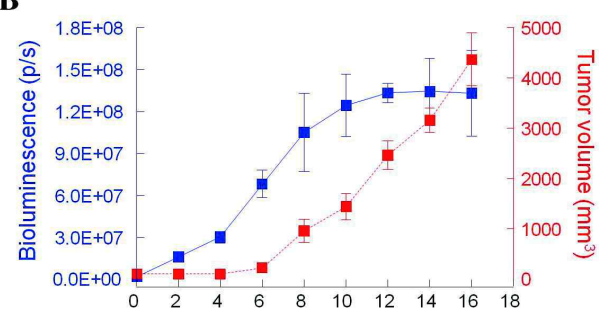

Day

C

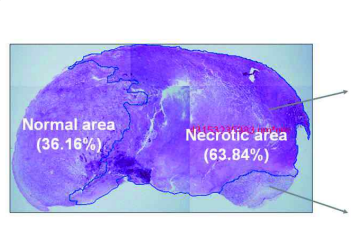

D
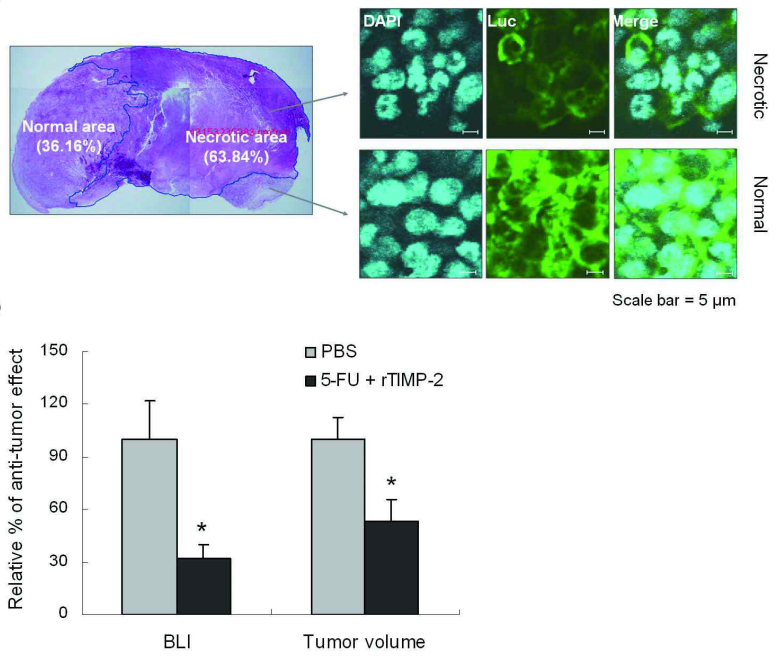

Fig. 2. Monitoring of tumor growth and drug efficacy in prostate cancer xenografts. (A) Representative bioluminescence images of a prostate cancer xenograft over time. (B) Determination of tumor growth by BLI and tumor volume measurement $(n=5)$. (C) Representative images of H\&E staining (left panel) and fluorescence immunostaining (right panel) of a tumor section 16 days after MLL-Luc injection. (D) Antitumor effect of chemotherapy determined by BLI and tumor volume in MLL-Luc xenografts. The quantitative data from the mean values represent the average \pm SEM ( $n=5$ /group). Significant difference: * $p<0.05$, Student's $t$-test. post-implantation, at which point it reached a plateau, whereas tumor volume continued to increase after 10 days. Differences between tumor growth based on BLI analysis and those measured with calipers at the late stage have been attributed largely to the fact that a tumor mass comprises necrotic, as well as viable, cells $[3,7,9]$. As the bioluminescence signal is derived only from viable MLL-Luc cells, and not from necrotic cells, BLI analysis yields a lower estimate of tumor growth than that based on tumor volume measurements. The low bioluminescence signal can be explained by the decreased expression of luciferase in the developing necrotic areas (Fig. 2C); this presumably contributed to the lower estimate of tumor growth.

To evaluate the usefulness of the bioluminescent cells in anticancer treatment, we compared tumor growth determined by BLI and by caliper measurements in MLL-Luc xenograft models receiving combination therapy. These models were injected i.p. with $5-\mathrm{FU}(50 \mathrm{mg} / \mathrm{kg})$ and rTIMP-2 $(60 \mathrm{mg} / \mathrm{kg})$ every 2 days, beginning 5 days after injection [5]. At day 16, BLI analysis estimated significant suppression of tumor growth $(68.2 \pm 7.9 \%)$, whereas caliper measurements showed only a moderate decrease (47.3 \pm $12.5 \%)$, demonstrating the advantage of BLI using bioluminescent MLL cells (Fig. 2D).

A

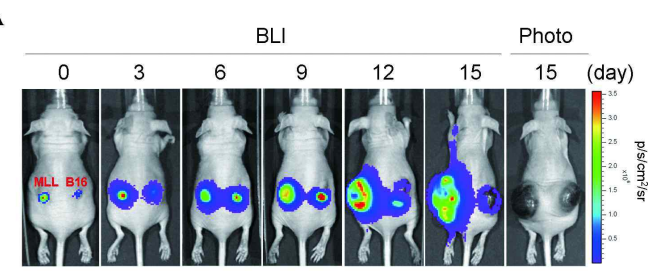

B
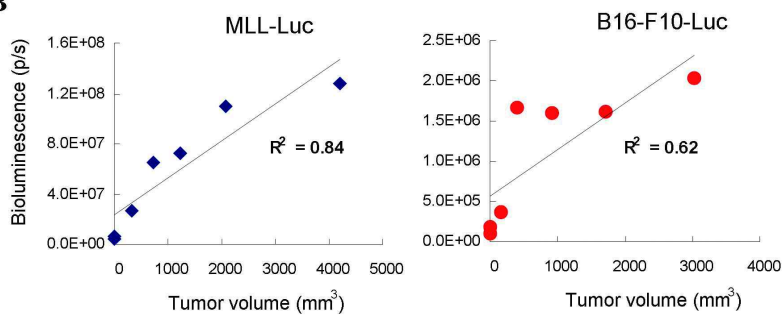

Fig. 3. Comparison of tumor growth determined by BLI of MLL-Luc and B16-F10-Luc-G5 cells in the same xenografted mouse. (A) Time course of tumor growth by BLI. Each mouse received subcutaneous injections of $5 \times 10^{5}$ MLL-Luc (MLL) cells and $5 \times 10^{5}$ B16-F10-Luc-G5 (B16) cells into different sides of its dorsal flank. Images were taken over time after injection. (B) Correlation between the bioluminescence signal and tumor volume based on caliper measurements, determined at the indicated time points $(n=3)$. 
Compared to commercially available B16-F10-Luc-G5 cells, the MLL-Luc cells showed more rapid tumor growth (Fig. 3A) and a stronger correlation between BLI and tumor volume ( $\mathrm{R}^{2}$ : 0.84 vs. 0.62 for MLL-Luc vs. B16-F10-luc-G5 cells; Fig. 3B). The reduced bioluminescence intensity of B16-F10-Luc-G5 might have been due to optical quenching of the bio-activating light by melanin pigment in the later stages of tumor growth.

In conclusion, our MLL-Luc tumor xenograft model is useful for studies of dynamic tumor progression and offers a rapid and accurate monitoring tool for preclinical assessment of anticancer drugs.

\section{Acknowledgment}

This study was supported by KBSI grant (Grant No. K3008E) to PI HS and the Ministry for Health, Welfare and Family Affairs (Grant No. A091037), Republic of Korea.

\section{References}

1. Brutkiewicz, S., M. Mendonca, K. Stantz, K. Comerford, R. Bigsby, G. Hutchins, M. Goebl, and M. Harrington. 2007. The expression level of luciferase within tumour cells can alter tumour growth upon in vivo bioluminescence imaging. Luminescence 22, 221-228.

2. Cui, K., X. Xu, H. Zhao, and S. T. Wong. 2008. A quantitative study of factors affecting in vivo bioluminescence imaging. Luminescence 23, 292-295.

3. Edinger, M., Y. A. Cao, Y. S. Hornig, D. E. Jenkins, M. R. Verneris, M. H. Bachmann, R. S. Negrin, and C. H. Contag. 2002. Advancing animal models of neoplasia through in vivo bioluminescence imaging. Eur. J. Cancer 38, 2128-2136.

4. Fan, F. and K. V. Wood. 2007. Bioluminescent assays for high-throughput screening. Assay Drug Dev. Technol. 5, 127-136.

5. Kang, W. K., E. K. Park, H. S. Lee, B. Y. Park, J. Y. Chang, M. Y. Kim, H. A. Kang, and J. Y. Kim. 2007. A biologically active angiogenesis inhibitor, human serum albumin-TIMP2 fusion protein, secreted from Saccharomyces cerevisiae. Protein Expr. Purif. 53, 331-338.

6. Kim, T. S., H. S. Choi, B. Y. Ryu, G. T. Gang, S. U. Kim, D. B. Koo, J. M. Kim, J. H. Han, C. K. Park, S. Her, and D. S. Lee. Real-time in vivo bioluminescence imaging of lentiviral vector-mediated gene transfer in mouse testis. Theriogenol. 73, 129-138.

7. Klerk, C. P., R. M. Overmeer, T. M. Niers, H. H. Versteeg, D. J. Richel, T. Buckle, C. J. Van Noorden, and O. van Tellingen. 2007. Validity of bioluminescence measurements for noninvasive in vivo imaging of tumor load in small animals. Biotechniques 43, 7-13, 30.

8. Lee, M. S., E. H. Kwon, H. S. Choi, S. H. Kwon, C. H. Lee, I. S. Shim, S. K. Lee, and S. Her. Quantification of cellular uptake and in vivo tracking of transduction using real-time monitoring. Biochem Biophys. Res. Commun. 394, 348-353.

9. Lyons, S. K. 2005. Advances in imaging mouse tumour models in vivo. J. Pathol. 205, 194-205.

10. Minn, A. J., Y. Kang, I. Serganova, G. P. Gupta, D. D. Giri, M. Doubrovin, V. Ponomarev, W. L. Gerald, R. Blasberg, and J. Massague. 2005. Distinct organ-specific metastatic potential of individual breast cancer cells and primary tumors. J. Clin. Invest. 115, 44-55.

11. Nogawa, M., T. Yuasa, S. Kimura, J. Kuroda, K. Sato, H. Segawa, A. Yokota, and T. Maekawa. 2005. Monitoring luciferase-labeled cancer cell growth and metastasis in different in vivo models. Cancer Lett. 217, 243-253.

12. Scatena, C. D., M. A. Hepner, Y. A. Oei, J. M. Dusich, S. F. Yu, T. Purchio, P. R. Contag, and D. E. Jenkins. 2004. Imaging of bioluminescent LNCaP-luc-M6 tumors: a new animal model for the study of metastatic human prostate cancer. Prostate 59, 292-303.

\section{초록 : 효과적인 항암효능측정을 위한 발광 전립선 세포의 개발 및 평가}

이미숙 ${ }^{12} \cdot$ 정재인 ${ }^{1,5} \cdot$ 권승해 ${ }^{1} \cdot$ 심인섭 $^{2} \cdot$ 함대현 $^{2} \cdot$ 한정준 $^{3} \cdot$ 한대석 $^{4} \cdot$ 윤정한 ${ }^{5} \cdot{\text { 허송욱 }{ }^{*}}^{*}$

(한국기초과학지원연구원 춘천센터, ${ }^{2}$ 경희대학교 한의학연구소, ${ }^{3}$ 두산 글로 넷, ${ }^{4}$ 한국식품연구원 식품자원이 용연구본부, ${ }^{5}$ 한림대학교 식품영양학과)

기존의 동물모델에서 암의 성장은 caliper를 이용하여 고형암 부피를 측정으로써 조사하였으나, 암 조직 속의 괴사와 부종으로 인하여 부피측정에 신뢰성이 결여 되어 있다. 이러한 문제점을 해결하기 위해 발광 암세포를 이용하여 광학생체영상적으로 분석하는 방법이 개발 되었다. 본 연구에서는 전립선 발광 암세포를 제조하여 고 형암 동물모델에서 B16 발광 암세포와 암 성장을 비교 측정하여 신규발광 암세포를 평가하였다. In vitro에서 세 포 수와 발광강도는 높은 상관관계를 보였고 $\left(\mathrm{R}^{2}=0.99\right)$, 고형암 동물모델에서 암 성장 측정은 괴사에 의한 오차를 줄였다. 이러한 발광신호를 기반으로 한 측정방법은 caliper의 부피 측정에 비하여 높은 항암효과를 보임으로써 기존의 발광 암세포보다 신규 발광전립선 암세포의 유용성을 증명하였다. 